\title{
LOVE (OF GOD) AS A MIDDLE WAY BETWEEN DOGMATISM AND HYPER-RATIONALISM IN ETHICS
}

\author{
Kyla Ebels-Duggan
}

\begin{abstract}
In the Groundwork Kant asserts that the fundamental moral principle must be a principle of autonomy. He dismisses theistic principles, along with all other competitors to his Categorical Imperative, claiming that they are heteronomous. I argue that the best case for this Kantian conclusion conflates our access to the reasons for our commitments with an ability to state these reasons such that they could figure in an argument. This conflation, in turn, results from a certain Kantian conception of inclination, and its role in our moral psychology. These are views that we ought to reject. Having done so, we will see that a theistic ethics based on desire or love for God need not face a distinctive problem of heteronomy.
\end{abstract}

Kant claims that a principle of action that makes reference to God could not be the fundamental moral principle. In both the Groundwork of the Metaphysics of Morals and the Critique of Practical Reason he dismisses theistic principles, along with all other competitors to his Categorical Imperative. He claims that they are principles of heteronomy, while the fundamental moral principle must be a principle of autonomy. ${ }^{1}$ Most contemporary Kantians, and many other contemporary thinkers as well, agree that an approach to ethics founded on theistic commitments would face some distinctive problem of heteronomy. But the nature of this purported problem is less than transparent, and Kant's own reasons for rejecting ethical views that are theistic in this sense are not what one might have thought. I will argue that, in fact, Kant's rejection of a theistic moral principle in these texts has surprisingly little to do with theism, but instead turns on some of his more general commitments about moral psychology, commitments that we ought to reject.

After briefly clarifying Kant's stance towards theistic ethics in the first section, in the second I examine his argument for the uniqueness of the Categorical Imperative (CI). Kant claims that the $\mathrm{CI}$ is the only possible

${ }^{1}$ Immanuel Kant, Groundwork, 4:441-445; Critique of Practical Reason, 5:82-86. 
fundamental moral principle. To establish this, he argues that it is the only principle that could be fully justified, and so the only one the authority of which could be accepted non-dogmatically, and thus autonomously. But this argument relies on what I will call a hyper-rationalist conception of autonomy, on which you can endorse a practical principle autonomously only if you can reason to it and so answer all intelligible skeptical challenges that could be brought against it.

The appeal of the hyper-rationalist standard in turn depends on conflating our access to the reasons for our commitments with an ability to state these reasons, to capture them in propositional form. If we treat access as requiring this sort of articulacy, then the only alternative to hyper-rationalism would be accepting practical convictions without reason, that is, dogmatically. To locate a middle ground between these two extremes, we need a way of actively appreciating or grasping reasons that does not require us to be articulate about these reasons, capable of reporting what they are. In section III I argue that a certain conception of desire-and more particularly love-is well suited to play this role, and so that a theistic ethics grounded in the love of God could occupy the middle ground, avoiding dogmatism without putting its adherent in a position to defend all of her commitments in terms that would move a skeptic.

In section IV I explain how Kant's own conception of the nature of desire and its role in our moral psychology obscures this possibility. Kant's Groundwork argument for the uniqueness of the CI depends on a particularly stark dualism concerning sensible and rational motives. On this dualistic view, we are subject to two distinct sorts of motives or incentives to action: inclinations that precede reasoning and a unique rational motive that follows from reasoning. But, on independent grounds, we ought to reject the idea that these two categories of motivation exhaust the possibilities. Having done so we can see that a theistic ethic based on desire or love for God need not face a distinctive problem of heteronomy.

\section{Kant on the Unique Status of the Categorical Imperative}

When Kant dismisses theistic principles as candidates for the fundamental moral law, he gives them plenty of good company. He claims that theistic principles have the same failing as all prior attempts to state the fundamental moral principle: They are principles of heteronomy, while the moral principle must be a principle of autonomy. Here is how he puts it in the Groundwork:

If we look back upon all previous efforts that have ever been made to discover the principle of morality, we need not wonder now why all of them had to fail. It was seen that the human being is bound to law by his duty, but it never occurred to them that he is subject only to laws given by himself but still universal. . . For, if one thought of him only as subject to a law (whatever it may be), this law had to carry with it some interest by way of attraction or constraint, since it did not as a law arise from his will; in order to conform with the law, his will had instead to be constrained by something else to act in 
a certain way. By this quite necessary consequence, however, all the labor to find a supreme ground of duty was irretrievably lost. For, one never arrived at duty but instead at the necessity of an action from a certain interest. . . . But then the imperative had to turn out always conditional and could not be fit for a moral command. I will therefore call [the categorical imperative] the principle of the autonomy of the will in contrast with every other, which I accordingly count as heteronomy. ${ }^{2}$

Any interpreter of Kant's argument faces the challenge of how to understand his ideal of autonomy, and the contrasting threat of heteronomy, in a way that can make sense of the claim that the CI- "act only in accordance with that maxim through which you could at the same time will that it become a universal law" 3 - is the only possible principle of autonomy.

Before turning to this question directly, it bears notice that Kant's claims about the unique status of the CI are in one way weaker and in another way stronger than one might initially think. His position is weaker than we might think in that he rejects theistic and other principles only as candidates for the fundamental moral law, or what he here calls "the principle of morality." That is, he claims that, like all other possible practical principles, if principles that make essential reference to God assert genuine obligations, they do so only in virtue of their relation to the CI. If they have authority, this authority is derivative from that fundamental principle. ${ }^{4}$ Importantly, his argument here does not depend on denying the antecedent of the conditional, and so does not purport to rule out the possibility that the theistic principles are authoritative.

Compare this to the practical principle: Advance the happiness of others. Taken in a maximizing way this is the utilitarian's candidate for the fundamental moral law. But Kant thinks that this principle, like others, could not have that fundamental status. Even so, he ultimately affirms the authority of this principle, though in a non-maximizing version. That is, he thinks that we really do have reasons - categorical moral reasons no less - to advance the happiness of others. ${ }^{5}$ He claims only that these reasons can't be fundamental. They are, instead, derivative from the CI; their authority depends on, or is justified by appeal to, its authority.

${ }^{2}$ Kant, Groundwork, 4:432-433.

${ }^{3}$ Kant, Groundwork, 4:419. This is the formulation of the Categorical Imperative usually called the Formula of Universal Law (FUL). Compare the Formula of Autonomy (FA): “Do no action on any other maxim than one such that it would be consistent with it to be a universal law, and hence to act only so that the will could regard itself as at the same time giving universal law through its maxim" (4:434). In my view, FA is not different in content from FUL, the statement of which I find somewhat more perspicuous. But Allen Wood lays great emphasis on the claim that FA is the definitive statement of the CI and rejects the idea that the statements are equivalent (Wood, Kantian Ethics).

${ }^{4}$ Elsewhere Kant makes the stronger claim that we could not have duties to God, but his reasons for this are independent of the argument under consideration here. They are grounded in his epistemic commitments and require independent assessment. See Kant, Metaphysics, 6:443-444. For more detail, see n33.

${ }^{5} \mathrm{Or}$, as I prefer to say, reasons to make their ends our own. See Ebels-Duggan, "Against Beneficence." For Kant's argument see Metaphysics of Morals, 6:387-389. 
For all Kant says in the argument we are considering, a theistic principle might have the same status. And, in fact, his rejection of a theistic fundamental moral principle notwithstanding, Kant's practical philosophy incorporates theistic commitments. He claims that, while morality does not depend on religion, it "leads to" religion. That is, he thinks that one can argue from moral commitments established on independent grounds to the rational necessity of what he calls "moral faith" in God. ${ }^{6}$ Kant also claims that, though the fundamental moral principle is not a theistic principle, we must nevertheless "recognize" or "regard" our duties as God's commands. ${ }^{7}$ The details of these arguments, and the meaning of their conclusions, need not concern us here. But their presence in Kant's system clearly indicates that Kant does not deny the authority of all theistic practical principles, and in fact holds that a complete moral philosophy has to make reference to God. Even so, he consistently maintains that no theistic principle could be the fundamental moral principle on account of the fact that all such principles are heteronomous.

His claim about the uniqueness of the $\mathrm{CI}$ is also stronger than one might think, in that it asserts, not only that competitors are not the fundamental moral principle, but that they could not be. They are not even candidates for this role. Kant thinks that theistic principles not only have the wrong content to be fundamental moral principles, but that they are the wrong sort of principles. They have the wrong form. That is why, as he puts it, all of the previous attempts to identify the fundamental moral principle not only failed, but "had to fail." ${ }^{8}$

To make a start on understanding Kant's claim about form, consider the proposal that the fundamental moral principle is the following: Human beings are inherently selfish. Kant will reject this proposal, of course, and moreover his rejection will not depend on an assessment of the truth of what the claim asserts. If we agree with him that practical principles must be imperatives, then we will likewise reject it. Whether we think that this

\footnotetext{
${ }^{6}$ Exactly how we should understand this argument is a matter of interpretive dispute. For my own account, see Ebels-Duggan, "The Right, the Good, and the Threat of Despair." For some competing accounts see Hare, The Moral Gap; Wood, Kant's Moral Religion; Neiman, The Unity of Reason; Sussman, "Something to Love." For discussion of Kant's distinction between "theological morality," which he rejects, and "moral theology," which he endorses, see Kain, "Interpreting Kant's Theory of Divine Commands."

${ }^{7}$ Kant, Critique of Practical Reason, 5:129. Cf Religion, 6:99. Notably, Religion 6:160 asserts that acting from love of God just is acting from the distinctively moral motive of duty: "Do your duty from no other incentive except the unmediated appreciation of duty itself, i.e. love God (the Legislator of all duties) above all else." I think that most readers, whether or not they are sympathetic to the case that we can act autonomously from love, will resist this identification, and such resistance is warranted. Among other considerations, Kant clearly understands the moral motive as a motive to which we can reason, one that "follows on" rather than "preceding" practical reasoning. But no line of reasoning could conclude with an attitude that we would recognize as love. While we can reason to the judgment that someone is lovable or that there is good reason to love her, these judgments are not the same as love itself. I return to this thought below, in section III. For more see Ebels-Duggan, "Love and Agency."

${ }^{8}$ Kant, Groundwork, 4:432.
} 
claim about human beings is true or false does not matter here. The claim is not the right sort of thing to serve as a fundamental moral principle. It's not a candidate. It has the wrong form.

Considering the larger context of the argument of the Groundwork can help us grasp the point. There Kant offers an argument for the authority of the CI in two steps. In the first he asks, If there were a moral law, what would it have to be? He states and defends the $\mathrm{CI}$ as an answer to this conditional question, and he argues that we can derive the content of this unique candidate moral principle from the formal requirements on the very idea of a moral principle. Only then does he turn to the second question, whether there really is a moral law, construing this as whether the CI-the only possible candidate-genuinely has authority. ${ }^{9}$ Importantly, Kant dismisses theistic principles in the first of these two steps. So, he thinks that we can reject theistic principles without so much as considering their particular content, because they have the wrong form. This puzzling statement is an important clue to how Kant understands the ideal of autonomy, one that we must keep in mind as we proceed.

So far, I have explained how Kant's claim that the CI is the sole principle of autonomy is in one way weaker and in one way stronger than one might think. It is weaker in that it does not rule out the authority of other practical principles, but claims only that any such authority would have to derive from that of the $\mathrm{CI}$. And it is stronger in that it claims that theistic principles are not possible principles of autonomy; they are not candidates for the fundamental moral law. We will not be in a position to evaluate, or even fully understand, these Kantian claims until we have an account of his conception of "autonomy" and "heteronomy." I turn to this task in the next section.

\section{Kantian Autonomy: From the Rejection of Dogmatism to Hyper-Rationalism}

In the Groundwork passage quoted above, Kant introduces the claim that the moral principle must be a principle of autonomy. He also asserts that all possible principles of action are either principles of autonomy, arising from one's own will, or principles of heteronomy, grounded in some interest. We need an understanding of both sides of this purportedly exhaustive division. In this section, I focus on first. My strategy will be to ask how Kant's argument for the claim that the CI is the only possible principle of autonomy is supposed to work, and then to use this to illuminate the conception of autonomy to which it must refer. I will lay out a reading that takes the form of a regress on rational conditions. The argument purports

\footnotetext{
${ }^{9} \mathrm{Cf}$. Korsgaard's introduction to Kant's Groundwork. The argumentative structure of the second Critique is somewhat different, but not in a way that matters for our purposes. There also Kant begins by arguing that the mere concept of a moral law determines that the moral law must be a principle of autonomy, and the CI is the only possible principle of autonomy. What differs is that he no longer seems to think that he needs to provide an argument that establishes the authority of the CI by showing how it can motivate us. Instead he treats it as a "fact of reason" that we can be motivated by our recognition of its authority.
} 
to show that our reasons for regarding any practical principle as authoritative would have to derive from the authority of the CI, while the CI itself is, in a significant sense, self-authenticating. ${ }^{10}$

We may begin this argument by considering any practical principle that someone might accept as authoritative. For example, we might consider a person who acts on the following principle: Never do something that is inconsistent with your honor, but act always as honor demands. ${ }^{11}$ This person regards acting in a way consistent with his honor as required, something that he must do, whether or not he wants to. In the same way, we could begin with someone for whom a principle making reference to God plays this same role, a person who takes acting as God wills, or commands, or for God's sake to be an authoritative practical principle for her. ${ }^{12}$

Those who accept and act from some such principle are already autonomous in a minimal sense; such a person directs himself by a practical principle that he regards as authoritative, a requirement that he takes it that he must follow even at cost to things he wants. It would be apt to say that he regards this principle as a law for himself. But Kant thinks that there is still a problem of heteronomy in both of these cases, that such a person must think of himself "only as subject to a law (whatever it may be)."

One might naturally think that Kant's objection to the principles under consideration would be that they direct their agents to rely on an authority external to them. This may seem a particularly apt diagnosis of the theistic agent, but we might similarly understand acting on a principle of honor as treating society's conventions as an external authority. However, this reliance on authority cannot be the whole story about what troubles Kant here, for neither Kant nor contemporary Kantians reject the possibility of legitimate authority. Kant's political philosophy not only allows, but requires this possibility. ${ }^{13}$ So, when he dismisses theistic ethics as heteronomous, he must have something more particular in mind.

Suppose our agents began to doubt or question the authority of their principles. They could settle these questions if they understood and affirmed the reasons that ground the principles, where these could include reasons to accept and defer to certain external sources of authority. For instance, in his political philosophy Kant seeks to give an argument for the legitimate authority of the institutions of the state. ${ }^{14}$ Assuming that his

\footnotetext{
${ }^{10} \mathrm{Cf}$. Korsgaard's introduction to Kant's Groundwork, and also “Kant's Analysis of Obligation." Other important passages from Kant include: Groundwork, 4:399-402, the conclusion of the argument of Groundwork I, which ends with the first statement of the CI; 4:420-422, the passage in Groundwork II in which Kant argues that the content of the CI, in its universal law formulation, can be derived from the mere concept of the CI; and 4:440, where he claims that the CI is the sole principle of autonomy, and commands "neither more nor less than just this autonomy."

${ }^{11} \mathrm{Cf}$. "Idea for a Universal History," 26.

${ }^{12}$ Korsgaard uses this example in both texts cited above.

${ }^{13} \mathrm{Cf}$. Pallikkathayil, "Deriving Morality from Politics."

${ }^{14}$ See, especially, The Doctrine of Right in Metaphysics or Morals. For detailed reconstruction of this argument see Ebels-Duggan, "Moral Community."
} 
argument is sound, an agent who reasons through it can conclude that the government's authority is legitimate. This would render the principle respect the authority of the government self-imposed or autonomous in a further, significant sense: It is the agent's own conclusion, the conclusion of her own reasoning. ${ }^{15}$ Reasoning is something that the agent does, her own activity, so that when she reasons to the conclusion that some principle is authoritative, it makes sense to say that she gives that principle to herself. ${ }^{16}$

So here we have a more sophisticated view of autonomy, on which an agent counts as acting autonomously just so long as she can reason to the principle on which she acts. On this reading, Kant's concern about heteronomy is a concern about justification or the lack thereof. Since a true principle of autonomy is susceptible to the sort of justification that would allow an agent to reason to it for herself, it is not enough for the principle to have some justification. That justification must be accessible to the agent who accepts and guides herself by the principle. Only if she can give the argument for the principle on which she acts, reasoning through this argument for herself, can she accept or maintain her commitment to the principle on the basis of this reasoning and so, in the relevant sense, autonomously. By contrast, an agent who depends on an external authority absent an understanding of the reasons that support doing so could only affirm the standing of this authority dogmatically.

Now, suppose that we ask the agents that we are considering the justificatory question about their principles, and so raise the doubts for them. We ask the person of honor: Why think that the fact that an action is required by your society's code of honor is sufficient to require you to do it? Or we inquire of the theistic agent: Why suppose that you are required to do as God commands? Faced with such a question, an agent who continues to affirm his principle has two apparent choices; he must either give reasons for maintaining his commitment or continue to regard it as authoritative without such justification. ${ }^{17}$ The latter option appears to render him dogmatic. On the other hand, an agent who gives some justification will thereby appeal to a further practical principle that he treats as more fundamental than the one he is defending. Whether or not the agent answers the justificatory challenge, then, any practical principle the authority of which can be intelligibly questioned cannot serve as the fundamental moral principle.

\footnotetext{
${ }^{15}$ Since Kant identifies the will and practical reason, we could also say that it is the conclusion of her will. Kant, Groundwork, 4:412 and cf. 4:427.

${ }^{16} \mathrm{Cf}$. Hieronymi, "Two Kinds of Agency." See also, Korsgaard, "The Activity of Reason."

${ }^{17} \mathrm{Kant}$ 's discussion of the possibility of appealing to God as the ground of moral obligation at Groundwork 4:443 can be read as presenting this dilemma. If we are to obey God, it is because of God's moral perfection or his power. But if it is the former, we must have some account of moral perfection that justifies this attribution, and that account then provides our more fundamental moral commitment. The latter is the wrong sort of thing to ground the moral law. It could only be affirmed dogmatically.
} 
Moreover, to escape a regress of further intelligible questioning, such an argument cannot depend on any premises that are themselves open to question. It must rely only on commitments about which no meaningful skeptical questions can arise. ${ }^{18}$ So, on this strong conception, the fully autonomous person is capable of answering all meaningful skeptical questions about her commitments, and of doing so in a way that appeals only to premises that the skeptic accepts, arguments that should move a skeptic from his own point of view. I will call this very strong conception of autonomy hyper-rationalism.

At this point one might wonder what principle could possibly escape the dilemma above. In developing her constructivist interpretation of Kant's Groundwork argument, Christine Korsgaard raises this question and provides an answer. She writes:

Kant concludes that the will must be autonomous: that is, it must have its own law or principle. And here again we arrive at the problem. For where is this law to come from? If it is imposed on the will from outside then the will is not free. So the will must make the law for itself. But until the will has a law or principle, there is nothing from which it can derive a reason. So how can it have any reason for making one law rather than another?

Well, here is the Kantian answer. The categorical imperative, as represented by the Formula of Universal Law, tells us to act only on a maxim which we could will to be a law. And this, according to Kant, is the law of a free [or autonomous] will. ${ }^{19}$

The Kantian constructivist purports to avoid dogmatic acceptance of her fundamental principle by demonstrating that affirmation of its authority is already contained in the question about whether it has authority. On Korsgaard's interpretation, to ask of any candidate practical principle whether it really is authoritative is to ask whether it is properly regarded as a law. Applied to any other principle, this question demands an answer and so generates the dilemma above. That's the feature that Kant picks out when he says that all of these other principles are of the wrong form to serve as the fundamental moral principle. But if you try to query the $\mathrm{CI}$ in this same way, you are simply asking the question that the $\mathrm{CI}$ itself directs you to ask, namely, is the principle on which I am acting fit to be regarded as a law? That is to say, raising the justificatory challenge is itself an application of the principle, and so it amounts to affirming the CI. This,

\footnotetext{
${ }^{18}$ Compare Korsgaard, The Sources of Normativity, 33 (cf. 12, 38-39):

Realism is a metaphysical position in the exact sense criticized by Kant. We can keep asking why: "Why must I do what is right?" - "Because it is commanded by God." -"But why must I do what is commanded by God?" - and so on, in a way that can apparently go on forever. This is what Kant called a search for the unconditioned -in this case, for something which will bring the reiteration of "but why must I do that?" to an end. The unconditional answer must be one that makes it impossible, unnecessary, or incoherent to ask why again.

${ }^{19}$ Korsgaard, The Sources of Normativity, 98.
} 
then, is where intelligible justificatory queries come to an end, and it is this that renders the $\mathrm{CI}$ the unique principle of autonomy. ${ }^{20}$

Many interpreters of Kant believe that we should not saddle him with this, admittedly radical, hyper-rationalist conception of autonomy. But we have seen an important consideration in favor of doing so: the hyper-rationalist conception makes sense of Kant's, otherwise puzzling, very strong claims about the uniqueness of the CI. The same cannot be said of some other leading attempts to explicate Kant's conception of this central notion. Consider, for example, Allen Wood's influential realist interpretation of Kant's argument. Wood holds that autonomy is the "capacity to govern our own lives according to rational principles," and that we are fully autonomous when we act on objectively justified principles, that is, principles that don't just purport to be, but really are, authoritative practical laws. ${ }^{21}$ On Wood's view, it is simply because the CI is just such an objectively authoritative practical principle that the agent who governs herself by it is an autonomous agent. ${ }^{22}$ So calling the CI a principle of autonomy is then nothing more than a fancy way of saying that that principle is right, one that we ought to follow.

One may then wish to ask Wood the sort of question that we imagined addressed to the theist and the person of honor, above: On what grounds should we affirm the authority of the CI? What is the objective justification to which you refer? Wood responds to this query, rather unhelpfully, by quoting Kant's claim from his Lectures on Ethics that the CI has objective authority "in the nature (or essence) of things." ${ }^{23}$ In particular he claims that the nature of the rational will makes it the case that the CI has this authority. The idea that the will is practical reason, and so constituted by

\footnotetext{
${ }^{20}$ This constructivist strategy faces a well-known worry that it renders the $\mathrm{CI}$ an empty formalism. In order to answer that challenge, the Kantian constructivist needs to show something beyond the case already developed: she needs to show that the mere form of law constrains the substance of the particular principles of action that can be willed as a law. That is, she must show that some substantive principles may, and others must, be regarded as laws just in virtue of their formal properties. Kant may be addressing this sort of challenge when he runs through a series of examples purporting to demonstrate actual constraints that the CI imposes at Groundwork 4:421-424. And cf. Korsgaard, "Kant's Formula of Universal Law." If this or a similar attempt succeeds, the Kantian constructivist can derive guiding, authoritative normative commitments just from the formal demands that would apply to any such commitment. She would thereby meet the demanding hyper-rationalist standard. She would also make sense of both the idea that we give the moral law to ourselves and the idea that this law has objective content, two claims that Kant clearly affirms, but which are, on the face of it, in serious tension with one another. Wood denies that these two ideas can be reconciled (Wood, Kantian Ethics, 106-122).
}

${ }^{21}$ Wood, Kantian Ethics, 106.

${ }^{22}$ Wood, Kantian Ethics, 116-122. See, especially, 119:

The moral law is not a law of autonomy because we stand in some relation of sovereign authority to the law, as we would if we were the author of merely positive or statutory laws. It is the law of autonomy only insofar as we succeed in aligning our will with what the law objectively commands, thus actualizing the nature of our will as a faculty of practical reason.

${ }^{23}$ Wood, Kantian Ethics, 114. 
the norms of practical reason, including moral norms, figures in Wood's argument. ${ }^{24}$ But he does not explain the grounds on which we should think that the very principles that Kant endorses, including the $\mathrm{CI}$, are these constitutive norms of the will. Elsewhere, he seems to deny that such an argument could be given or should be sought. ${ }^{25}$

Wood's interpretation cannot capture Kant's aims or argumentative strategy in the Groundwork. For, of course, advocates of the competitor principles Kant dismisses also regard their candidate principles as objective, that is as genuine authoritative practical laws. Kant argues that these principles are-at best-derivatively authoritative, because they are principles of heteronomy. But Wood's interpretation would require Kant to reverse the order of this argument. Rather than claiming that competitors are not the fundamental principle of practical reason because they are not principles of autonomy, Wood would have Kant claiming that they are principles of heteronomy because they are not genuine practical laws. An appeal to autonomy in Wood's sense could thus give no grounds for ruling out a theistic, or any other, principle. Identifying a principle as heteronomous would merely report the fact that we have already, on some independent basis, ruled it out. But recall that Kant asserts that the $\mathrm{CI}$ is the unique principle of autonomy prior to purporting to establish its authority, and he rules out the competitors without attention to their content, based solely on their form. Wood's reading can make no sense of this.

Wood's conception of autonomy is less demanding than the hyperrationalist standard. But, precisely because of this, it also fails to vindicate Kant's claim that the CI is the unique principle of autonomy, and so the unique candidate for a fundamental moral principle. While I have not argued that any alternative to the hyper-rationalist reading of autonomy will fail in a similar way, all such readings face the challenge of explaining Kant's argument for the uniqueness of the CI. Meeting this challenge is far from trivial.

So far, then, we have seen that Kant claims that, while theistic principles could be authoritative, the $\mathrm{CI}$ is the only principle that could possibly be the fundamental moral principle. He tells us that this is because the $\mathrm{CI}$ is the uniquely autonomous principle. And we have gleaned his meaning from the argument that he provides for the CI's unique status: it is the only principle about which no intelligible justificatory question

\footnotetext{
${ }^{24}$ Wood, Kantian Ethics, 115-116. As with the (closely related) claim that the CI is the sole principle of autonomy, Wood seems to be reasoning to this claim about constitutive norms from the claim that the norms in question are objectively valid. So understood, the argument obviously does not give us any reason to accept the claim that they are objectively valid.

${ }^{25}$ Wood, Kantian Ethics, 89, 93. What Wood is directly opposing in these passages is the idea that we could provide a compelling argument for the claim that humanity is objectively valuable. This is very closely related to the question about whether the $\mathrm{CI}$ is authoritative, or a constitutive norm of the will, both because of the way that the value of humanity figures in one of Kant's formulations of the CI, and because Wood himself understands the task of identifying an objective end as equivalent to showing how the rational will could be moved to act on a categorical imperative.
} 
can be raised, and so the only one the authority of which we can affirm non-dogmatically. This argument construes autonomy as a matter of meeting the hyper-rationalist standard; an agent can act autonomously on a principle if, but only if, she can give an argument for that principle that would answer all intelligible skeptical challenges to it. And only the agent who acts from the CI can do that.

\section{Middle Ground}

The appeal of the hyper-rationalist conception of autonomy depends largely on the suggestion that the two alternatives that Kant mentions in the Groundwork passage really are exhaustive, so that anything short of meeting the hyper-rationalist standard would amount to dogmatism. But in this section I suggest a middle path between dogmatism and hyper-rationalism and explain why this middle path seems open to someone who affirms a theistic fundamental ethical principle.

To resist the pressure to hyper-rationalism, while yet avoiding dogmatism, we need to understand how it is possible to have access to, understand, and affirm the reasons for our commitments, while lacking full articulacy about these reasons. Happily, we have some familiar models available to us. ${ }^{26}$ Consider the affirmation that Shakespeare's plays are great works of literature. One way to come to this view is by accepting it on someone else's say-so, perhaps that of one's apparently authoritative high school teacher. While the authority of the teacher may give grounds for supposing that there are sufficient reasons to affirm the claim, someone who adopts the view based solely on testimony in this way would have no insight into the content of these reasons. ${ }^{27}$ Since it is held without understanding of the reasons justifying it, even if a normative attitude formed in this way could be warranted, we might reasonably identify it as dogmatic.

Contrast what it is like to read the plays and thereby come to appreciate or love them. One might well benefit from the guidance of the teacher in this endeavor, but one would no longer be dependent on the authority of her report in one's assessment of the work. Assuming that Shakespeare's works really are great, coming to affirm this through developing an appreciation of them seems paradigmatically autonomous; one experiences for oneself the value that one affirms, and one arrives at the normative attitude on the basis of that experience. It would be wrong to think of a soformed affirmation of Shakespeare's greatness as dogmatic in any sense.

But one who appreciates, and perhaps even comes to love, Shakespearean dramas in this way may yet be unable to say what it is that makes the work great. She may be unable to give, that is, to report, the reasons for her conviction that this is so. Even if she can say something, she will almost certainly fall short of the hyper-rationalist standard; she will not be able to answer all intelligible skeptical questions nor put the reasons for her love

${ }^{26}$ Here I draw on the argument in Ebels-Duggan, "Beyond Words."

${ }^{27} \mathrm{Cf}$. Tenenbaum, Appearances of the Good, on direct and oblique access to value. 
in the form of an argument that would convince a Shakespeare skeptic by his own lights.

In fact, something stronger is true. It must be impossible in principle to capture fully the reasons for her love in an argument that could be reported to third parties. For if a sound argument fully captures the reasons for the attitude that it defends, it can convince us of its conclusion and thereby bring us to adopt the attitude in question. Think about what it is like to reason through a mathematical proof. If you reason through the proof, and understand it, you draw the conclusion, and that just is to acquire the belief that that conclusion is true. So, if it were possible to state fully the reasons to love Shakespeare's plays in the form of an argument, then anyone who could follow the reasoning laid out in that argument could thereby reason to love of the works as a conclusion. That would render reading the plays an eliminable step in coming to love them. A teacher who aimed to inspire love of Shakespeare in her students wouldn't need to give them the plays to read, but could instead simply tell them what makes the plays great. But, in fact, this isn't possible. Using that method, a teacher could, at best, get her students to believe that Shakespeare's works are great, but to believe this is not yet to love them. No line of reasoning can substitute for the role that encounter with the texts themselves plays in arriving at love. Only someone who has read the works, who has experienced and appreciated them for herself, can affirm their worth in the non-dogmatic way that students who read, appreciate, and so come to love the plays do. Though accepting a positive assessment of Shakespeare's works based just on a report of their good-making features might count as autonomous, coming to this assessment in response to the works themselves would be more, not less, so.

Love of other persons seems to have this same structure. In loving another, I appreciate directly the value that grounds my commitment, the value of the person that I love. This direct appreciation does not yield an ability to capture the reasons justifying my love in articulable claims, propositions that could be presented to a skeptic as a full account of the reasons for my love. As with love of a literary work, the reasons grounding interpersonal love must outrun our ability to report them, even in principle. ${ }^{28}$ For, again, if they did not, then someone could come to share your love of a person just by reasoning through some argument that you present. But this seems to be impossible, not just psychologically but conceptually. In order to love a person, you must know her; it is not enough to simply know some things about her. ${ }^{29}$ Though we can have reasons for love, love

\footnotetext{
${ }^{28} \mathrm{Cf}$. Setiya, "Love and the Value of a Life."

${ }^{29}$ In the normal case, we encounter those whom we come to love directly in real life. Our love arises from appreciation of them that is forged in interactions with them. It may also be possible to love a person whom you've not met on the basis of sufficiently vivid stories about them. If so, then there is a sense in which you could come to love a person on the basis of mere report. But a story is not an argument, and this does not show that you could come to love a person by reasoning to that love.
} 
cannot be the conclusion of a line of reasoning in the way that a belief or a decision to act can. ${ }^{30}$

If all of this is right, then commitments constituted by or grounded in interpersonal love not only standardly do not, but in principle cannot, meet the hyper-rationalist standard. Those who have these commitments are unable to articulate compelling reasons for them, yet it would be wrong to think of their affirmation of the value of those they love as dogmatic. Like the student who appreciates Shakespeare's plays, the lover bases her commitment on her own experience of the value she affirms, and there is nothing dogmatic about that. ${ }^{31}$

It seems to me that many, arguably all, of our important normative commitments work in accordance with this model. They are not a matter of affirming some normative view dogmatically, as if by mere report, with no insight into the reasons for doing so. Nor do they meet the hyper-rationalist standard on which we can give a complete defense of our view, reasoning to it in a way that ought to move any skeptic. Among such commitments are many actual instances of religious commitment, and an attractive model of theistic ethics would draw on this, placing love of God at its foundation. ${ }^{32}$ To guide oneself by this ethic would be to live out one's love for God, obeying God's commands or seeking to emulate God's character or do God's will as an expression of this love. It would be inaccurate to classify normative commitment based on love of God, or theistic ethics so conceived, as in principle, or necessarily, dogmatic in the same way that it would be wrong to classify the students' response to their appreciation of Shakespeare this way. ${ }^{33}$

Could such an approach to ethics count as autonomous? Certainly not on the hyper-rationalist version of autonomy, on which the autonomous person must be able to say what her reasons are. Religious commitment would not meet this standard, but neither would my appreciation of Shakespeare or my love for my children. I am not able to argue doubters into accepting these values either. Rather than casting aspersions on all

\footnotetext{
${ }^{30}$ For more development of the case of love see Ebels-Duggan, "Love and Agency."

${ }^{31} \mathrm{Cf}$. Velleman, "Love as a Moral Emotion," and Gaita, A Common Humanity, especially 259-285.

${ }^{32} \mathrm{Cf}$. Adams, Finite and Infinite Goods. I will not defend this way of thinking about theistic ethics against alternatives at any length here, but it seems to me more continuous with Christian theological traditions, and probably other monotheistic traditions as well, than alternatives that figure more prominently in the philosophical literature.

${ }^{33}$ Other parts of Kant's view raise independent objections to at least some theistic approaches. In the first Critique Kant famously rejects the idea that we can have any knowledge concerning God (Bxxx). But see Andrew Chignell, "Belief in Kant." Even absent Kant's distinctive epistemological views, many readers will worry that we have to have some independent argument for God's existence before the position that I am suggesting here is available to us. And in the Doctrine of Virtue in the Metaphysics of Morals, Kant argues on conceptual grounds that we can have no duties to God. Engaging with these arguments is beyond the scope of this paper. The objection to theistic ethics that I address here is just that the sort of submission to God that it demands is incompatible with autonomy. That objection is usually presented as downstream from, and independent of, either of these other challenges.
} 
of these commitments, we should instead reject the purported ideal of autonomy that would tell against them. ${ }^{34}$ If what I've said in this section is right, then love can provide the basis on which we do so, the middle way between dogmatism and hyper-rationalism that we seek.

\section{$I V$. Why Kant(ians) Can't Find the Middle Path}

The examples of normatively significant, autonomously affirmed attitudes for which we have reasons, but to which we cannot reason indicate that dogmatism and hyper-rationalism are not exhaustive alternatives. But in the Groundwork Kant treats them as if they were. In the passage quoted in section I, he holds that the only alternative to autonomy is thinking of ourselves "only as subject to a law," dogmatically accepting its authority. In this section, I explain how Kant's argument for the unique status and authority of the CI depends on regarding this dichotomy as exhaustive.

Kant interprets any agent who does not act from the $\mathrm{CI}$ as acting from inclination. Moreover, in the Groundwork he thinks of inclinations on an empiricist model of desire, as mere psychological pressures or forces. The argument recognizes only two kinds of motives: the moral motive, to which we can reason, and inclinations for which we can have no reason. The former meets the hyper-rationalist standard. But the latter can be granted authority only dogmatically; like a literal push, inclination so construed has no intelligible content of the sort that could be either questioned or justified. So Kant construes an agent who acts from inclination as treating the fact that she has such a motive as her reason for acting. He is right to think that this attitude cannot be justified, and so could be affirmed only dogmatically. But he is wrong about the range of agents who can plausibly be so interpreted. In particular, it is implausible to assimilate agents who act from love, including love of God, to this model.

All of this requires more explanation, but let's start with an example. As Christmas approaches, Calvin is doing his very best to act as if he were good. Among other things, he tries to follow the rule, Do not throw snowballs at Susie. His motive for following the rule is what Kant would call an inclination or material incentive. Such incentives direct one towards the production of some outcome. In this case, Calvin wants to get more Christmas loot, more gifts under the tree. He believes that acting as if he is good is a means to this end, and he believes that acting this way includes not throwing snowballs at Susie. So he adopts the no-snowballs principle as his rule.

Calvin meets the weakest standard of autonomy: he acts on a principle that he accepts as authoritative. But I think that most will agree that, even if he manages to refrain from snowball throwing, he does not thereby act from a moral principle. He may be acting in accord with duty, but he is not acting from duty. Since Calvin's principle is not the unique principle of autonomy, the CI, Kant would regard Calvin as heteronomous in the

${ }^{34}$ Cf. Ebels-Duggan, "Christian Philosophy and the Christian Life." 
sense that most interests him. He has to think of Calvin's fundamental principle of action as a principle of heteronomy.

Let's think about what this fundamental principle is. Suppose we put the question of justification to Calvin. We ask him why he thinks he is required not to throw snowballs at Susie. He does have a sort of reason for refraining from snowball throwing, namely, that it is conducive to, even required for, securing one of his ends, acquiring the loot. This end, in turn, is given by his desire. Kant would have him say that he refrains from snowball throwing as a means to get what he most wants, or to produce the outcome towards which he is inclined. As Calvin thinks of it, the imperative not to throw snowballs at Susie binds him only because, and so long as, he continues to want to acquire the loot, and indeed to want this more than any competing alternative. If he were to decide that the loot was worth sacrificing for the delight of hitting Susie with a snowball, then he would not act irrationally when he hurled the snowball, at least not as far as this principle is concerned. So Calvin treats the fact that he wants a thing as the fundamental reason to pursue it. In later work, Kant calls the fundamental principle of the agent so motivated the principle of self-love. ${ }^{35}$

Contrast this interpretation of Calvin's reasons for acting with our standard thinking about epistemic reasons. We often cite some belief as a reason for doing or believing some further thing. But we are rarely tempted to think that the reason cited is conditioned on the fact that we have the belief. Except in odd cases, it is the content of the belief, the presumed truth of what is believed, rather than the fact that I believe it, that I take to provide reasons. Standardly, if these reasons hold, they do so whether or not I have the belief, though without the belief I would lack access to them such that they could not figure in my thinking.

The interpretation of Calvin on offer is quite different. In reducing his motive just to the principle of self-love, the Kantian view under consideration has him regarding the fact that he wants something, without regard to the content of what is wanted, as sufficient to create reasons for him to act. It construes him as taking that fact as both given and fixed. There is no space here for him to consider whether he has reason to want what he wants, whether it is a thing worth wanting, because on this view wantsinclinations or material incentives - aren't a kind of attitude for which we can have reasons. They are just psychological pressures, not the sort of thing about which a person could deliberate, but merely part of the background against which he acts.

Once we accept this way of thinking about desires, and regard Calvin as acting from self-love in Kant's sense, it's not hard to see why he would count as dogmatic. For we can raise a meaningful justificatory question about the principle of self-love: Why regard the fact that one wants something-where this just means that one experiences some psychological pressure towards it-as a reason to do it? By hypothesis, Calvin has no

${ }^{35}$ Kant, Religion, 6:36. 
answer for this question. Kant thinks that there is no satisfactory answer to be given. Calvin is thus dogmatic about the authority of the desires that occur in him in just the way that the caricatured theist is imagined as dogmatic about acting on the commands of God.

This is a plausible reading of Calvin. As the paradigmatic six-year-old, Calvin is impulsive. He just goes for whatever he wants, and so he's reasonably regarded as taking his desires-just as such-as authoritative directives. But Kant's argument for the CI's unique status as a principle of autonomy depends on generalizing this analysis of Calvin's practical thought and action to any agent who regards something other than the CI as her fundamental principle. All other agents, he claims, also treat the fact that they want a thing as giving them sufficient reason for action, and so act from the principle of self-love. So, like Calvin, they dogmatically affirm the principle of self-love that assigns their desires ultimate authority.

One can construct a theistic approach to ethics that mirrors Calvin's approach to Christmas in just this way. Someone might regard his reasons to obey God as instrumental and so act from a theistic principle in order to receive a divine reward or to avoid divine punishment. ${ }^{36}$ This is perhaps the most common version of theistic ethics invoked by philosophers, though usually just in passing. And it is plausible to think of that person as acting, ultimately, from the principle of self-love, just going for what he wants for the reason that he wants it. ${ }^{37}$ An agent who acts to please God just for the reason that he likes doing that, and-at the limit-an agent who just wants to stand in the relation of obedience to God could, likewise, be construed as acting from self-love. All of these agents find themselves inclined towards some outcome, and they believe that following God's commands is a means to producing it. If they are correctly understood as taking the mere fact that they are so inclined as their reason, then they are not importantly different from someone motivated by honor, pleasure, money, or whatever else. All of these agents simply yield to the psychological pressure of their desires.

But the examples laid out in section III indicate that this is not the only, nor even the most plausible, way to construe agents who act from desires to which they neither do nor can reason. The person who acts from love of God would normally understand her own reasons quite differently. It may be true of her that she wants to please God or act for God's sake, but she

\footnotetext{
${ }^{36} \mathrm{Cf}$. Critique of Practical Reason, 5:41. Kant claims there that God's will could be the ground of our action in only two ways. First, by appeal to "an antecedent practical principle independent of this idea." Here, I take him to refer to the regress on rational conditions that I describe in section I: Obey God may be an authoritative practical principle, but its authority derives from a more fundamental one. The second, and only remaining, possibility is that the will of God grounds our actions "only by means of the happiness we expect" from adhering to it. This is the assimilation of the agent who embraces a theistic principle to the model that describes Calvin's attitude towards Christmas. So, in this passage Kant affirms his dualism about fundamental motives, and he executes the strategy of assimilating all motives other than the distinctively moral motive of the $\mathrm{CI}$ to acting from the principle of self-love.
}

${ }^{37}$ This seems to be how Kant imagines the sympathetic helper in Groundwork 4:398. 
need not take the reasons that she has to do these things as conditioned on her having these desires. Agents who understand themselves as acting out of love for God are more likely to think that the reasons to which they respond would hold even if their desires were different. They regard their desire-their love for God-as providing them with access to or insight into reasons that exist independently of it, just as beliefs standardly provide access to epistemic reasons. Since they cannot reason to this love, they do not meet the hyper-rationalist standard. But, like the lover of Shakespeare or of another human being, the love may nevertheless provide insight into the values and reasons to which their action responds.

Kant's failure to entertain this possibility depends on thinking that only motives to which we can reason could provide such insight. And that, in turn, depends on construing any desire as just another arational inclination, a psychological force, not the sort of thing that could be responsive to reasons. If inclinations - and desires, and loves - were nothing but psychological forces, then their content could not be the source of our reasons in the way that the content of a belief can be reason to believe something further. In fact, they would not have such content at all. An agent who treats an inclination as reason-giving could then only be regarding the fact that he has a desire as his reason. It is because he is thinking of any motive to which we do not reason in these terms that Kant can conclude that their purported authority is in every case captured by a dogmatic, and so heteronomous, principle of self-love. It is on the basis of this argument that Kant dismisses in one fell swoop all alternatives to the CI. Theistic principles are caught up among the casualties.

But a better view of desire-or of attitudes to which we do not reason more generally - would not force us to choose between dogmatism and hyper-rationalism. The middle path that I am trying to stake out would be more satisfying if paired with a more complete positive account of the conception of love or desire than I've given so far. The sense in which someone who loves can "have reasons" for her love and the actions that she takes from it needs to sit between two alternatives. On the one hand, as I have been concerned to stress, the reasons to which love gives us access are not standardly reasons that the agent they govern should be capable of articulating or reporting. Taken to its limit, a requirement for full articulacy about our reasons just is hyper-rationalism. It is the demand that we keep giving reasons until we cite something that it is not intelligible to question further. That standard is too strong. But on the other hand, having reasons in this way must go beyond the bare idea that there are reasons, that the commitments that we have are good ones. That standard is too weak. Reasons of this latter kind can attend a merely dogmatic commitment, such as the affirmation of Shakespeare's greatness based solely on a teacher's report. We need an account of love and desire that makes it the case that in loving, it is we ourselves who are responsive to reasons, that we are active in determining what we love, but not by reasoning to it. 
In texts beyond the Groundwork, Kant begins to develop more nuanced and compelling views of desire along these lines, and some of his contemporary inheritors are carrying this project forward..$^{38}$ These are welcome developments, but they will require other revisions in a Kantian view. Most importantly, if we adopt a view of desire as an attitude that can be had for reasons and reveal reasons to act, it becomes unclear why acting from desire should be regarded as heteronomous. But it does seem that a wide middle ground lies between hyper-rationalist and dogmatic motives. Love of other persons is in this middle ground, and in principle love of God can be found there too. There need be nothing dogmatic or distinctively heteronomous about action from love so conceived. And if love itself can be an expression of our autonomy, then a theistic ethic based on love of God could be autonomous in any sense that should matter. ${ }^{39}$

Northwestern University

\section{References}

Adams, Robert Merrihew. 1999. Finite and Infinite Goods: A Framework for Ethics (Oxford University Press).

Chignell, Andrew. 2007. "Belief in Kant." Philosophical Review 116, no. 3: 323-360. https://doi.org/10.1215/00318108-2007-001

Ebels-Duggan, Kyla. 2008. "Against Beneficence: A Normative Account of Love." Ethics 119: 142-70. https://doi.org/10.1086/592310

Ebels-Duggan, Kyla. 2009. "Moral Community: Escaping the Ethical State of Nature." Philosophers' Imprint 9, no. 8: 1-19. Permalink: http://hdl.handle.net/2027/ spo.3521354.0009.008.

Ebels-Duggan, Kyla. 2015. "The Right, the Good, and the Threat of Despair: (Kantian) Ethics and the Need for Hope in God." In Oxford Studies in the Philosophy of Religion, edited by Jon Kvanvig (Oxford University Press).

Ebels-Duggan, Kyla. Forthcoming. "Beyond Words: Inarticulable Reasons and Reasonable Commitments." Philosophy and Phenomenological Research.

Ebels-Duggan, Kyla. Forthcoming. "Christian Philosophy and the Christian Life." In Christian Philosophy: Conceptions, Continuations, and Challenges, edited by J. Aaron Simmons (Oxford University Press). https://doi.org/10.1111/phpr.12463 Ebels-Duggan, Kyla. Forthcoming. "Love and Agency." In Routledge Handbook of Love, edited by Adrienne Martin (Routledge).

Gaita, Raimond. 2000. A Common Humanity (Routledge).

\footnotetext{
${ }^{38}$ See, e.g., Religion 6:211-214. For an informed discussion of Kant's concept of inclination, sensitive to a wide range of his texts, see Wilson, "Habitual Desire." For contemporary Kantian developments see Schapiro, "The Nature of Inclination"; "What Are Theories of Desire Theories Of?"; "On the Relation between Wanting and Willing"; and "Foregrounding Desire." And see Korsgaard, "From Duty and for the Sake of the Noble."

${ }^{39} \mathrm{I}$ am grateful to a generous audience at the Theistic Ethics Workshop at Wake Forest and to Sarah Buss, Ryan Davis, Mark Murphy, and Jada Twedt Strabbing for discussion of earlier drafts of this paper.
} 
Hare, John E. 1996. The Moral Gap: Kantian Ethics, Human Limits, and God's Assistance (Oxford University Press).

Hieronymi, Pamela. 2009. "Two Kinds of Agency." In Mental Actions, edited by Lucy O'Brien and Matthew Soteriou (Oxford University Press), 138-162.

https://doi.org/10.1093/acprof:oso/9780199225989.003.0007

Kain, Patrick. 2005. “Interpreting Kant's Theory of Divine Commands." Kantian Review 9: 128-149. https://doi.org/10.1017/S136941540000203X

Kant, Immanuel. 1963. "Idea for a Universal History from a Cosmopolitan Point of View." In Kant on History, edited by Lewis White Beck (MacMillen).

Kant, Immanuel. 1996. The Metaphysics of Morals. Translated by Mary J. Gregor (Cambridge University Press). https://doi.org/10.1017/CBO9780511809644

Kant, Immanuel. 1997. Critique of Practical Reason. Translated by Mary J. Gregor (Cambridge University Press). https://doi.org/10.1017/CBO9780511809576.004

Kant, Immanuel. 1998a. Critique of Pure Reason. Translated by Paul Guyer and Allen W. Wood (Cambridge University Press).

https://doi.org/10.1017/CBO9780511804649

Kant, Immanuel. 1998b. Groundwork of the Metaphysics of Morals. Translated by Mary J. Gregor (Cambridge University Press). https://doi.org/10.1017/CBO9780511809590.004

Kant, Immanuel. 1999. Religion within the Boundaries of Mere Reason. Translated by Allen Wood and George di Giovanni (Cambridge University Press).

Korsgaard, Christine M. 1996a. “Kant's Analysis of Obligation in Groundwork I." In Creating the Kingdom of Ends (Cambridge University Press), 43-76.

Korsgaard, Christine M. 1996b. "Kant's Formula of Universal Law." In Creating the Kingdom of Ends (Cambridge University Press), 77-105.

Korsgaard, Christine M. 1996c. The Sources of Normativity (Cambridge University Press). https://doi.org/10.1017/CBO9780511554476

Korsgaard, Christine M. 2008. "From Duty and for the Sake of the Noble." In The Constitution of Agency: Essays on Practical Reason and Moral Psychology (Oxford University Press), 203-236.

Korsgaard, Christine M. 2009. "The Activity of Reason." Proceedings and Addresses of the American Philosophical Association 83. Permalink: http://nrs.harvard.edu/ urn-3:HUL.InstRepos:3415961.

Neiman, Susan. 1994. The Unity of Reason (Oxford University Press).

Pallikkathayil, Japa. 2010. “Deriving Morality from Politics: Rethinking the Formula of Humanity." Ethics 121: 116-147. https://doi.org/10.1086/656041

Schapiro, Tamar. 2009. “The Nature of Inclination." Ethics 119: 229-256. https://doi.org/10.1086/596469

Schapiro, Tamar. 2011. "Foregrounding Desire." Journal of Ethics 15: 147-167. https://doi.org/10.1007/s10892-011-9110-6

Schapiro, Tamar. 2012. "On the Relation between Wanting and Willing." Philosophical Issues 22: 334-350. https://doi.org/10.1111/j.1533-6077.2012.00233.x

Schapiro, Tamar. 2014. "What Are Theories of Desire Theories Of?" Analytic Philosophy 55: 131-151. https://doi-org.proxy.library.georgetown.edu/10.1111/phib.12043

Setiya, Kieran. 2014. "Love and the Value of a Life." Philosophical Review 123: 251-280. https://doi.org/10.1215/00318108-2683522 
Sussman, David. 2010. "Something to Love: Kant and the Faith of Reason." In Kant's Moral Metaphysics, edited by Benjamin J. Bruxvoort Lipscomb and James Krueger (Walter de Gruyter).

Tenenbaum, Sergio. 2007. Appearances of the Good (Cambridge University Press). https://doi.org/10.1017/CBO9780511498855

Velleman, David. 2006. “Love as a Moral Emotion.” In Self to Self (Cambridge University Press), 70-109.

Wilson, Eric Entrican. 2016. "Habitual Desire: On Kant's Concept of Inclination." Kantian Review 21: 211-235. https://doi.org/10.1017/S1369415416000030

Wood, Allen W. 1970. Kant's Moral Religion (Cornell University Press).

Wood, Allen W. 2007. Kantian Ethics (Cambridge University Press). https://doi.org/10.1017/CBO9780511809651 